\title{
ZC.9.a.8040
}

Volume 4 a Issue 3

September 2011

\section{Industrial and}

\section{Organizational}

Psychology

\section{PERSPECTIVES ON SCIENGE AND PRACTICE}

Individual Psychological Assessment: A Practice and Science in Search of Common Ground

Rob Silzer and Richard Jeanneret

With commentaries by:

Joy Fisher Hazucha, Anuradha Ramesh, Maynard Goff, Stu Crandell, Charlotte Gerstner,

Elaine Sloan, Jurgen Bank, and Paul Van Katwyk

Nathan R. Kuncel and Scott Highhouse

Stephen A. Laser

Ute-Christine Klehe

Rodney L. Lowman

Scott B. Morris, Ilianna H. Kwaske, and Rebecca R. Daisley

Nancy T. Tippins

Rosanna Miguel and Suzanne Miklos

Joel Moses

Dennis Doverspike

- How Work-Family Research Can Finally Have an Impact in Organizations

Ellen Ernst Kossek, Boris B. Baltes, and Russell A. Matthews

With commentaries by:

Christopher J. L. Cunningham

Mark D. Agars and Kimberly A. French

Teresa J. Rothausen

Matthew J. Grawitch, Patrick W. Maloney, Larissa K. Barber, and Cali Yost

Ryan C. Johnson, Kaitlin M. Kiburz, Soner Dumani, Eunae Cho, and Tammy D. Allen

Kerstin Aumann and Ellen Galinsky

Debra A. Major and Valerie J. Morganson

Kimberly Wells

Jacqueline K. Deuling and Alison Mallard

Ann H. Huffman, Adriane M. Sanders, and Satoris S. Culbertson

Lisa M. Leslie and Colleen F. Manchester

Ariane Ollier-Malaterre

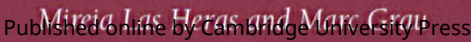




\section{A Journal of the Society for Industrial and Organizational Psychology}

\section{Editor \\ Cynthia D. McCauley, Center for Creative Leadership \\ Publications Manager \\ Jenny Baker, Society for Industrial and Organizational Psychology}

\section{Editorial Board}

Neil Anderson, Brunel University, United Kingdom Winfred Arthur, Jr., Texas A\&M University

Talya Bauer, Portland State University

Michael J. Burke, Tulane University

Allan H. Church, PepsiCo, Inc., Purchase, NY

José M. Cortina, George Mason University

Fritz Drasgow, University of Illinois at Urbana-Champaign

Miriam Erez, Technion, Haifa, Israel

Michael Frese, National University of Singapore

Mark A. Griffin, University of Western Australia

Milton D. Hakel, Bowling Green State University

Theodore L. Hayes, U.S. Office of Personnel Management Beryl Hesketh, University of Western Sydney, Australia

George P. Hollenbeck, Hollenbeck Associates, Livingston, TX

John R. Hollenbeck, Michigan State University

Leaetta M. Hough, Dunnette Group, Ltd., St. Paul, MN

Ann Howard, Retired, Naples, FL

Jeff Johnson, Personnel Decisions Research Institute, Minneapolis, MN

Jerard F. Kehoe, Selection and Assessment Consulting, Olympia, WA

Richard J. Klimoski, George Mason University

Allen I. Kraut, Baruch College, CUNY

Hennie J. Kriek, TTS - Top Talent Solutions (USA) and University of South Africa

Morgan W. McCall, University of Southern California Jeffrey J. McHenry, Microsoft Corporation, Seattle, WA

Kevin R. Murphy, The Pennsylvania State University

Kenneth Pearlman, Creative Personnel Management Consulting, Sarasota, FL

Hannah R. Rothstein, Baruch College, CUNY

Ann Marie Ryan, Michigan State University

Lise Saari, New York University

Eduardo Salas, University of Central Florida

John C. Scott, APT, Inc., Darien, CT

Robert F. Silzer, HR Assessment and Development Inc., New York, NY; Baruch College, CUNY

William J. Strickland, Human Resources Research

Organization (HumRRO), Alexandria, Virginia

Nancy T. Tippins, Valtera Corporation, Greenville, SC

\section{Industrial and Organizational Psychology: Perspectives on Science and Practice}

(ISSN 1754-9426) is published quarterly on behalf of the Society for Industrial and Organizational Psychology by Wiley Subscription Services, Inc., a Wiley Company, 111 River St., Hoboken, NJ 07030-5774. Blackwell Publishing, Inc. is now part of Wiley-Blackwell.

New orders, renewals, sample copy requests, claims, change of address information, and all other correspondence should be sent to Journals Customer Service at your nearest Wiley office.

Journal Customer Services: For ordering information, claims and any inquiry concerning your journal subscription please go to www.wileycustomerhelp.com/ask or contact your nearest office.

Americas: Email: cs-journals@wiley.com; Tel: +1 7813888598 or +1 8008356770 (toll free in the USA \& Canada).

Europe, Middle East and Africa: Email: cs-journals@wiley.com; Tel: +44 (0) 1865778315.

Asia Pacific: Email: cs-journals@wiley.com; Tel: +65 65118000.

Japan: For Japanese speaking support, Email: cs-japan@wiley.com; Tel: +65 65118010 or Tel (toll-free): 00531650480.

Visit our Online Customer Get-Help available in 6 languages at www. wileycustomerhelp.com

Subscription Rates Volume 4, 2011 - 4 issues:

\begin{tabular}{|c|c|c|c|c|}
\hline Annual Subscription & $\begin{array}{l}\text { The } \\
\text { Americas* }\end{array}$ & $\begin{array}{c}\text { Europe } \\
\text { (Euro Zone)** }\end{array}$ & $\begin{array}{l}\text { Europe (non- } \\
\text { Euro Zone)*** }\end{array}$ & $\begin{array}{l}\text { Rest of } \\
\text { World }\end{array}$ \\
\hline $\begin{array}{l}\text { Personal: Print + Online* } \\
\text { Institutional: }\end{array}$ & $\$ 103$ & $€ 81$ & $£ 51$ & $£ 54$ \\
\hline $\begin{array}{l}\text { Print + Premium Online** } \\
\text { Institutional: }\end{array}$ & $\$ 485$ & $€ 306$ & $€ 306$ & $\$ 472$ \\
\hline Premium Online Only & $\$ 421$ & $€ 266$ & $€ 266$ & $\$ 410$ \\
\hline
\end{tabular}

*Personal rate applies to subscriptions at a private address paid by personal check or credit card.

**Institutional premium rate includes online access to full text articles starting with 2011.

Where the subscription price includes print issues and delivery is to the recipient's address, delivery terms are Delivered Duty Unpaid (DDU); the recipient is responsible for paying any import duty or taxes. Title to all issues transfers FOB our shipping point, freight prepaid. We will endeavour to fulfil claims for missing or damaged copies within six months of publication, within our reasonable discretion and subject to availability.

Prices are exclusive of tax. Australian GST, Canadian GST and European VAT will be applied at the appropriate rates. For more information on current tax rates, please go to www. wileyonlinelibrary. com/tax-vat. The institutional price includes online access to the current and all online back files to January 1st 2007, where available. For other pricing options, including access information and terms and conditions, please visit www.wileyonlinelibrary.com/ access. Please visit www.siop.org for information about SIOP and the journal editorial policy.

This journal is available online at Wiley Online Library. Visit http://wileyonlinelibrary.com/ to search the articles and register for table of contents and e-mail alerts.

Access to this journal is available free online within institutions in the developing world through the HINARI initiative with the WHO. For information, visit www.healthinternetwork.org

Mailing: Journal is mailed Standard Rate. Mailing to rest of world by IMEX (International Mail Express). Canadian mail is sent by Canadian publications mail agreement number 40573520.

Postmaster: Send all address changes to Industrial and Organizational Psychology, Journal Customer Services, John Wiley \& Sons Inc., 350 Main' Street, Malden, MA 02148-5020.

Back Issues: Single issues from current and recent volumes are available at the current single issue price from Blackwell Publishing Journals. Earlier issues may be obtained from the Periodicals Service Company, 11 Main Street, Germantown, NY 12526, USA. Email: PSC@periodicals.com; Tel: (518) 537-4700; Fax: (518) 537-5899.

Copyright and Photocopying: @ 2011 Society for Industrial and Organizational Psychology. All rights reserved. No part of this publication may be reproduced, stored, or transmitted in any form or by any means without the prior permission in writing from the copyright holder. Authorization to photocopy items for internal and personal use is granted by the copyright holder for libraries and other users registered with their local Reproduction Rights Organisation (RRO), e.g. Copyright Clearance Center (CCC), 222 Rosewood Drive, Danvers, MA 01923, USA (www.copyright.com), provided the appropriate fee is paid directly to the RRO. This consent does not extend to other kinds of copying such as copying for general distribution, for advertising or promotional purposes, for creating new collective works or for resale. Special requests should be addressed to: permissionuk@wiley.com

Advertising: For advertising information please visit http://wileyonlinelibrary.com/ or contact the Journal Advertising Sales Coordinator at Corporatesalesusa@wiley.com, 350 Main Stieet, Malden, MA 02148; Tel: (781) 388-8532; Fax: (781) 338-8532.

This journal is printed on acid-free paper.

Wiley's Corporate Citizenship initiative seeks to address the environmental, social, economic, and ethical challenges faced in our business and which are important to our diverse stakeholder groups. We have made a long-term commitment to standardize and improve our efforts around the world to reduce our carbon footprint. Follow our progress at http://www.wiley.com/go/citizenship

Disclaimer: The Publisher, Society for Industrial and Organizational Psychology, and Editors cannot be held responsible for errors or any consequences arising from the use of information contained in this journal; the views and opinions expressed do not necessarily reflect those of the Publisher, Society, and Editors, neither does

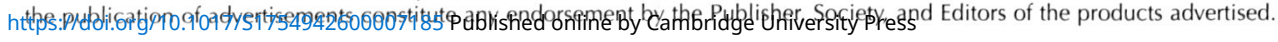

